\title{
MALLOMONAS CAMERUNENSIS SP. NOV. (CHRYSOPHYCEAE, STRAMENOPILES) FROM A SHALLOW PUDDLE IN THE GUINEO-CONGOLIAN RAINFOREST (CAMEROON)
}

\author{
Jolanta PiąTeK
}

\begin{abstract}
A new silica-scaled chrysophyte species, Mallomonas camerunensis J. Piątek, is described and illustrated from a shallow puddle in the Guineo-Congolian rainforest in Cameroon. This species belongs to section Papillosae and series Papillosa. It is similar to other Mallomonas species placed in Papillosa, such as M. binocularis Siver, M. calceolus D. E. Bradley, M. delanciana Siver, M. kalinae Řezáčová, M. papillosa K. Harris \& D. E. Bradley, M. paxillata (D. E. Bradley) L. Ş. Péterfi \& Momeu, M. rasilis Dürrschm. and M. tropica Dürrschm. \& Croome, but differs from them in several morphological characters warranting recognition as a distinct species. The dome of $M$. camerunensis is clearly delimited and ornamented with papillae and ribs. The scales lack an anterior submarginal rib, while the posterior rim and V-rib are smooth and unornamented. The shield is thickly ornamented with papillae (18-22 papillae per scale width). The species is described and illustrated using light microscopy and scanning electron microscopy.
\end{abstract}

Key words: Africa, Cameroon, Chrysophyceae, Mallomonas camerunensis, new species, scale morphology, Stramenopiles

Jolanta Piątek, Department of Phycology, W. Szafer Institute of Botany, Polish Academy of Sciences, Lubicz 46, 31-512 Kraków, Poland; e-mail: j.piatek@botany.pl

\section{INTRODUCTION}

Chrysophyte species are common algae in the plankton of freshwater habitats, rarely in brackish or saline waters, and many of them are considered cosmopolitan (Kristiansen \& Preisig 2001). Their greatest species diversity has been recorded from cold and nutrient-poor waters in the subarctic, boreal and temperature zones of the Northern Hemisphere (Cronberg 1989). Research on the diversity and ecology of chrysophytes in tropical and subtropical regions has been much neglected in the past (Vyverman \& Cronberg 1993). Systematic studies of tropical waters, especially at different seasons of the year, could fill the gap in this area of chrysophyte research, including discovery of species new to science, as has been recently substantiated in some tropical regions of the world, for example in Southeast Asia (e.g., Gusev 2012, 2015; Wei et al. 2014; Gusev et al. 2015).

As in other tropical areas, research and documentation of African chrysophytes is still far from satisfactory; up to now the most research has been done in the Democratic Republic of the
Congo (Belgian Congo), Sierra Leone (Woodhead \& Tweed 1957), Senegal (Woodhead \& Tweed 1959), Chad (Compère 1973, 1974, 1975), Kenya (Wujek \& Asmund 1979), Madagascar (Hansen 1996; Hansen \& Kristiansen 1995), Botswana (Cronberg 1996), Zimbabwe (Wujek et al. 2004), Nigeria (Wujek et al. 2004, 2010, 2011), Egypt (Piątek et al. 2009) and South Africa (Němcová et al. 2011; Němcová \& Kreidlová 2013).

In two surveys for chrysophytes (including stomatocysts) in Cameroon in 2007, several sediment and water samples were collected from different water reservoirs. The material included cells and scales of Mallomonas striata var. serrata K. Harris \& D. E. Bradley and Synura petersenii f. kufferathii J. B. Petersen \& J. B. Hansen, both newly recorded in Cameroon and Central Africa (Piątek \& Mossebo 2008), encysted specimens of Dinobryon sertularia Ehrenb. representing the first finding of an encysted chrysophyte in Africa (Piątek et al. 2012), as well as a new chrysophyte stomatocyst (stomatocyst 49 J. Piątek; Piątek \& Piątek 
2014). Another chrysophyte, an unknown species of Mallomonas Perty, was found in material collected from a shallow puddle in the Guineo-Congolian rainforest. This apparently undescribed species belongs to section Papillosae (Asmund \& Kristiansen 1986) and is described and illustrated here.

\section{MATERIALS AND METHODS}

The samples were collected on $12^{\text {th }}$ December 2007 from a shallow puddle in the Guineo-Congolian rainforest in the East Region of Cameroon. Plankton, water and sediment were taken using a pipette. The samples were fixed with Lugol's solution. Water temperature $\left({ }^{\circ} \mathrm{C}\right)$, conductivity $\left(\mu \mathrm{S} \cdot \mathrm{cm}^{-1}\right)$ and $\mathrm{pH}$ were measured immediately after collection. Temperature and conductivity were measured using a CC-102 conductivity meter (Elmetron IP67), and $\mathrm{pH}$ was measured using a CP-103 waterproof pH-meter (Elmetron IP67).

The specimens were examined and identified using standard light and phase contrast microscopy (LM) and scanning electron microscopy (SEM). Slide preparations mounted in water were observed using a Nikon Eclipse 600 light microscope. Micrographs were taken with a Nikon DS-Fil camera. For SEM analyses each sample was pipetted onto clean cover glasses, air-dried, and affixed to an aluminum stub with double-sided transparent tape. The stubs were sputter-coated with carbon using a Cressington sputter-coater and viewed with a Hitachi S-4700.

The description of the new Mallomonas species follows the terminology of Siver (1991), Kristiansen (2002) and Kristiansen \& Preisig (2007). All measurements of cells were taken from the present material directly under the light microscope, and scales and other elements were measured from SEM micrographs. The major diagnostic features of cells, scales and bristles of closely related taxa used to distinguish Mallomonas camerunensis sp. nov. are summarized in Table 1.

Wet samples and SEM holders are deposited in the Department of Phycology, W. Szafer Institute of Botany, Polish Academy of Sciences, Kraków.

\section{RESULTS AND DISCUSSION}

Mallomonas camerunensis J. Piątek, sp. nov.

Figs 1-11

TYPE: Cameroon, East Region, Department of HautNyong: between Ngolambélé and Dimako, ca $2 \mathrm{~km} \mathrm{~S}$ of Ngolambélé, $21 \mathrm{~km} \mathrm{SW}$ from Bertoua, $04^{\circ} 24^{\prime} 26^{\prime \prime} \mathrm{N}$, $13^{\circ} 35^{\prime} 52^{\prime \prime E}$, elev. ca $655 \mathrm{~m}$ a.s.1., leg. J. Piatek \& M. Piatek, 12 December 2007 (HOLOTYPE: Fig. 10).

LM DESCRIPTION. Cells oval and obovate with bristles, at least one chloroplast, and two flagella (long and short). Cells 23.5-24.2 $\mu \mathrm{m}$ long and 7.5-10.4 $\mu \mathrm{m}$ wide.

SEM DESCRIPTION. Cells 18.7-24.2 $\mu \mathrm{m}$ long and $9.0-10.0 \mu \mathrm{m}$ wide. Scales oval, ovate or rhomboid, tripartite, composed of a dome, shield, and flange; well-developed V-rib separates shield from posterior flange. Scales 3.5-4.4 $\mu \mathrm{m}$ long and 1.5-2.7 $\mu \mathrm{m}$ wide. Scales lack anterior submarginal rib. Posterior rim encircling up to half of perimeter of scale. Clearly delimited dome and shield, covered with densely spaced, well-developed papillae, $0.07-0.1 \mu \mathrm{m}$ in diameter; dome additionally ornamented usually with 1 to 4 ribs. Posterior flange smooth and unornamented. Bristles serrate, short, thick, slightly curved, without bifurcated tip, 6.5$11.2 \mu \mathrm{m}$ long and $0.2-0.4 \mu \mathrm{m}$ wide. Shield densely ornamented with papillae, 18-22 papillae per scale width (counted at place where V-rib ends).

\section{StOMATOCYST. Unknown.}

ETYMoLOGy. The epithet refers to the country where this species was found.

DisTRIBUTION. This species is currently known only from the type locality in eastern Cameroon.

Ecology. The material with Mallomonas camerunensis was collected in a semi-shaded place at the bottom of a disturbed rainforest from a small shallow puddle rich in leaf litter (Fig. 1); the pool resulted from overflowing of the neighboring river. The water was black, with temperature $24.5^{\circ} \mathrm{C}$, conductivity $26 \mu \mathrm{S} \cdot \mathrm{cm}^{-1}$ and $\mathrm{pH}$ 7.0. Mallomonas camerunensis co-occurred with other algae, especially with many specimens of Bacillariophyceae, colored and colorless Euglenophyta, and single specimens of Cyanophyta and Dinophyta.

Comments. Mallomonas camerunensis is a new species belonging to section Papillosae and series Papillosa of the genus Mallomonas. It has several distinct morphological features that warrant its description as a new species: (1) the dome is clearly delimited and ornamented with 


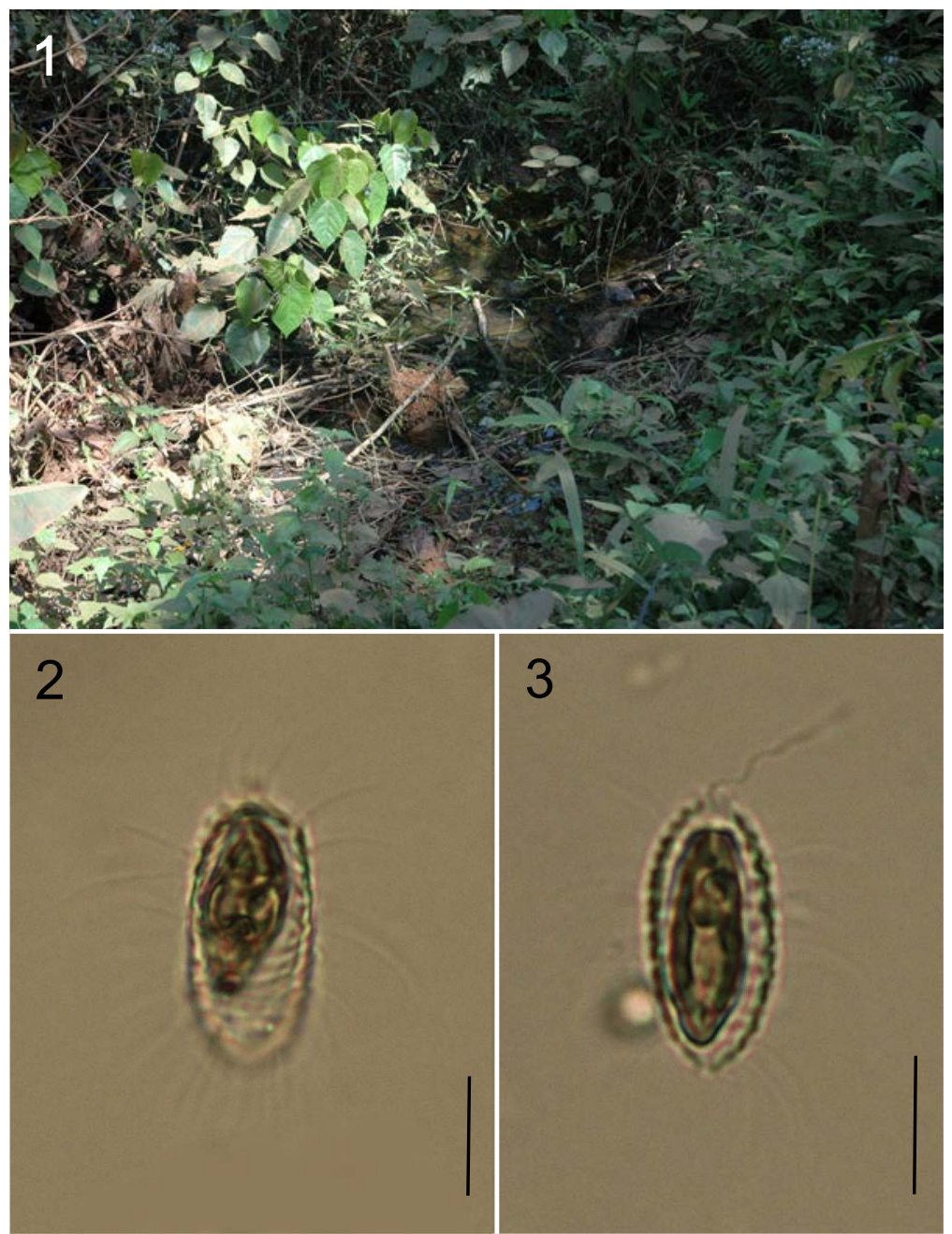

Figs 1-3. Mallomonas camerunensis J. Piątek, sp. nov. 1 - Sampling site (type locality) - shallow puddle in the Guineo-Congolian rainforest, Cameroon (photo M. Piątek). 2 \& 3 - Whole cells with scales and bristles (LM). Scale bars $=10 \mu \mathrm{m}$.

papillae and ribs, (2) the scales lack an anterior submarginal rib, (3) the posterior rim and V-rib are smooth and unornamented, (4) the shield is thickly ornamented with papillae (18-22 papillae per scale width). This species is assigned to section Papillosae. This section includes two series, Papillosa and Ouradiatae, with a total of 17 specific and infraspecific taxa (Kristiansen 2002; Řezáčová 2006; Kristiansen \& Preisig 2007; Gusev 2012). Mallomonas camerunensis is similar to several species from series Papillosa (Table 1), which are contrasted and discussed below.
Mallomonas binocularis Siver has shorter cells and scales than $M$. camerunensis, and the dome is ornamented with a few papillae, without ribs (ribs are present in M. camerunensis). Mallomonas binocularis differs from M. camerunensis in having two conspicuous pores resembling pair of eyes, situated in the V-rib angle (Kristiansen 2002), small tooth-like projections on the left side of the scale (absent in M. camerunensis), smooth bristles, and only 6-9 papillae per scale width (counted at place where V-rib ends, from pictures in Kristiansen 2002; Kristiansen \& Preisig 2007). 
Table 1. Comparison of Mallomonas camerunensis J. Piątek, sp. nov. with morphologically similar species (morphological

\begin{tabular}{|c|c|c|c|c|c|}
\hline Taxon & Cells & Scales & Dome & Shield & Posterior rim \\
\hline M. binocularis & $\begin{array}{l}\text { ovoid, } \\
8.0-12.0 \times \\
7.0-9.0 \mu \mathrm{m}\end{array}$ & $\begin{array}{l}\text { oval, } 2.2-2.7 \times \\
1.4-1.8 \mu \mathrm{m}\end{array}$ & $\begin{array}{l}\text { small with a few } \\
\text { papillae }\end{array}$ & $\begin{array}{l}\text { with papillae } \\
\text { and with two } \\
\text { conspicuous } \\
\text { pores }\end{array}$ & $\begin{array}{l}\text { usually extends less } \\
\text { than halfway around } \\
\text { perimeter of scale }\end{array}$ \\
\hline M. calceolus & $\begin{array}{l}\text { ovoid, } \\
11.0-18.0 \times \\
9.0-12.0 \mu \mathrm{m}\end{array}$ & $\begin{array}{l}\text { oval, suboval, } \\
3.0-4.0 \times \\
1.0-2.0 \mu \mathrm{m} \\
\end{array}$ & $\begin{array}{l}\text { smooth or with some } \\
\text { papillae }\end{array}$ & with papillae & N/A \\
\hline M. camerunensis & $\begin{array}{l}\text { oval, } \\
18.5-24.2 \times \\
7.5-10.4 \mu \mathrm{m}\end{array}$ & $\begin{array}{l}\text { oval, ovate, } \\
\text { rhomboid, } \\
3.5-4.4 \mu \mathrm{m} \times \\
1.5-2.7 \mu \mathrm{m}\end{array}$ & $\begin{array}{l}\text { with papillae and } \\
\text { ribs }\end{array}$ & with papillae & smooth \\
\hline M. delanciana & $\begin{array}{l}\text { ovoid, } \\
10.0-14.0 \times \\
8.0-9.0 \mu \mathrm{m}\end{array}$ & $\begin{array}{l}\text { elliptical, } \\
3.5-4.0 \times \\
2.0-2.7 \mu \mathrm{m}\end{array}$ & with papillae & with papillae & $\begin{array}{l}\text { usually extends less } \\
\text { than halfway around } \\
\text { perimeter of scale }\end{array}$ \\
\hline M. kalinae & $\begin{array}{l}\text { ellipsoid, } \\
15.0-17.5 \times \\
8.0-9.5 \mu \mathrm{m}\end{array}$ & $\begin{array}{l}\text { tripartite, } \\
3.7-3.9 \times \\
1.7-2.0 \mu \mathrm{m}\end{array}$ & small, smooth & $\begin{array}{l}\text { with small } \\
\text { papillae and one } \\
\text { or two pores in } \\
\text { proximal area }\end{array}$ & N/A \\
\hline M. papillosa & $\begin{array}{l}\text { broadly ellip- } \\
\text { soidal, } \\
7.0-12.0 \times \\
5.0-12.0 \mu \mathrm{m}\end{array}$ & $\begin{array}{l}\text { oval, } \\
2.0-4.0 \times \\
1.5-3.5 \mu \mathrm{m}\end{array}$ & $\begin{array}{l}\text { small, smooth or } \\
\text { partially covered } \\
\text { with papillae }\end{array}$ & with papillae & narrow \\
\hline M. paxillata & $\begin{array}{l}\text { ovoid, } \\
12.0-24.0 \times \\
9.0-12.0 \mu \mathrm{m}\end{array}$ & $\begin{array}{l}\text { suboval with } \\
\text { slightly lateral } \\
\text { incurving, } \\
4.0-5.7 \times \\
2.5-4.0 \mu \mathrm{m} \\
\end{array}$ & small, with papillae & with papillae & N/A \\
\hline M. rasilis & $\begin{array}{l}\text { ellipsoidal, } \\
15.0-20.0 \times \\
8.0-11.0 \mu \mathrm{m} \\
\end{array}$ & $\begin{array}{l}\text { suboval, } \\
3.0-4.1 \times \\
2.0-2.5 \mu \mathrm{m} \\
\end{array}$ & $\begin{array}{l}\text { smooth or with } \\
\text { papillae }\end{array}$ & with papillae & with irregular struts \\
\hline M. tropica & $\begin{array}{l}\text { ellipsoid, } \\
15.0-20.0 \times \\
5.0-9.0 \mu \mathrm{m}\end{array}$ & $\begin{array}{l}\text { body scales } \\
\text { oval, } 3.0-4.1 \times \\
2.0-2.2 \mu \mathrm{m}\end{array}$ & $\begin{array}{l}\text { small and rounded, } \\
\text { not clearly delimited } \\
\text { from the shield }\end{array}$ & $\begin{array}{l}\text { with papillae } \\
\text { except in the } \\
\text { angle of V-rib }\end{array}$ & N/A \\
\hline
\end{tabular}

* counted at place where V-rib ends

Mallomonas calceolus D. E. Bradley has shorter cells, and the dome is smooth or ornamented with papillae but without ribs (ribs are present in M. camerunensis). The anterior submarginal rib is weakly developed in M. calceolus (absent in $M$. camerunensis), the bristles are smooth with bifurcated tips and the number of papillae per scale width is 3-6 (counted in place where V-rib ends, from pictures in Kristiansen 2002; Kristiansen \& Preisig 2007).

Mallomonas delanciana Siver has shorter cells than M. camerunensis, and the dome is or- namented only with papillae (with papillae and ribs in M. camerunensis). An anterior flange is present in M. delanciana and ornamented with struts (absent in M. camerunensis), and the bristles are shorter, smooth and with a bifurcated tip, not serrate as in M. camerunensis. Moreover, the number of papillae per scale width is 4 (counted in place where V-rib ends, from pictures in Kristiansen 2002; Kristiansen \& Preisig 2007) in M. delanciana while 18-22 in M. camerunensis.

Mallomonas camerunensis is also similar to M. kalinae Řezáčová, but this latter species differs 
characters according to Kristiansen 2002; Řezáčová 2006; Kristiansen \& Preisig 2007).

\begin{tabular}{|c|c|c|c|c|c|c|}
\hline $\begin{array}{l}\text { Pores of } \\
\text { base plate }\end{array}$ & $\begin{array}{l}\text { Posterior } \\
\text { flange }\end{array}$ & $\begin{array}{l}\text { Anterior } \\
\text { flange }\end{array}$ & $\begin{array}{l}\text { Anterior sub- } \\
\text { marginal ribs }\end{array}$ & V-rib & $\begin{array}{l}\text { Number of papillae } \\
\text { per scale width* }\end{array}$ & Bristles \\
\hline N/A & smooth & smooth & usually lacking & broadly rounded & $6-9$ & $\begin{array}{l}\text { slightly curved, short, } \\
\text { thick, smooth, ending in } \\
\text { a distinct point, } \\
2.5-3.3 \mu \mathrm{m} \text { long }\end{array}$ \\
\hline lack & smooth & smooth & $\begin{array}{l}\text { weakly } \\
\text { developed }\end{array}$ & with hood & $3-6$ & $\begin{array}{l}\text { slightly curved, smooth } \\
\text { with bifurcated tip } \\
4.0-15.0 \mu \mathrm{m} \text { long }\end{array}$ \\
\hline lack & $\begin{array}{l}\text { smooth, } \\
\text { unorna- } \\
\text { mented }\end{array}$ & lacking & lacking & well developed & $18-22$ & $\begin{array}{l}\text { thick, slightly curved, } \\
\text { serrate, } \\
6.5-11.2 \mu \mathrm{m} \text { long, } \\
0.2-0.4 \mu \mathrm{m} \text { wide }\end{array}$ \\
\hline N/A & smooth & $\begin{array}{l}\text { with a series } \\
\text { of evenly } \\
\text { spaced, par- } \\
\text { allel struts }\end{array}$ & N/A & well developed & 4 & $\begin{array}{l}\text { small, ribbed, smooth } \\
\text { with bifurcated tip, } \\
3.4-3.5 \mu \mathrm{m} \text { long }\end{array}$ \\
\hline N/A & smooth & smooth & well developed & N/A & $11-14$ & $\begin{array}{l}\text { smooth, slightly curved } \\
\text { and pointed, } \\
4.1-7.7 \mu \mathrm{m} \text { long }\end{array}$ \\
\hline present & smooth & $\begin{array}{l}\text { with evenly } \\
\text { spaced struts }\end{array}$ & well developed & $\begin{array}{l}\text { narrow, hooded, } \\
\text { often toothed }\end{array}$ & $8-12$ & $\begin{array}{l}\text { slightly curved, with short } \\
\text { teeth, } 4.0-11.0 \mu \mathrm{m}\end{array}$ \\
\hline lack & smooth & with papillae & $\begin{array}{l}\text { well developed, } \\
\text { forming a tooth, } \\
\text { or obscure }\end{array}$ & $\begin{array}{l}\text { acute-angled, } \\
\text { narrow, hooded }\end{array}$ & $15-20$ & $\begin{array}{l}\text { short, slightly curved, } \\
\text { shaft smooth, with bifur- } \\
\text { cated tip, } \\
4.5-8.0 \mu \mathrm{m} \text { long }\end{array}$ \\
\hline lack & smooth & $\begin{array}{l}\text { narrow, with } \\
\text { papillae }\end{array}$ & $\begin{array}{l}\text { lacking or } \\
\text { inconspicuous }\end{array}$ & $\begin{array}{l}\text { with rounded } \\
\text { base and struts } \\
\text { and a large pore }\end{array}$ & $7-8$ & $\begin{array}{l}\text { unilaterally serrate, with } \\
\text { short, pointed teeth, } \\
6.0-15.0 \mu \mathrm{m} \text { long }\end{array}$ \\
\hline N/A & smooth & N/A & $\begin{array}{l}\text { with short struts, } \\
\text { the front part } \\
\text { much reduced }\end{array}$ & $\begin{array}{l}\text { with struts and } \\
\text { smooth hood }\end{array}$ & $9-10$ & $\begin{array}{l}\text { curved, serrated and } \\
\text { attenuated, } \\
8.0-16.0 \mu \mathrm{m} \text { long }\end{array}$ \\
\hline
\end{tabular}

in having a small, smooth dome. Additionally, the shield in M. kalinae is ornamented with papillae and one or two pores in the proximal area (pores absent in M. camerunensis), the anterior submarginal rib is well developed and smooth (absent in M. camerunensis), and the anterior flange is smooth (absent in M. camerunensis). Moreover, the number of papillae per scale width is ca 11-14 (counted in place where V-rib ends, from pictures in Řezáčová 2006; Kristiansen \& Preisig 2007) in M. kalinae, but 18-22 in M. camerunensis.

Mallomonas papillosa K. Harris \& D. E. Bradley has shorter cells, the dome is mainly smooth or partially covered with papillae, and pores of the base plate are present (absent in M. camerunensis). The number of papillae per scale width is 8-12 (counted in place where V-rib ends, from pictures in Kristiansen 2002; Kristiansen \& Preisig 2007) in M. papillosa (18-22 in $M$. camerunensis).

Mallomonas camerunensis is also similar to M. paxillata (D. E. Bradley) L. Ş. Péterfi \& Momeu but differs in lacking an anterior submarginal rib. The latter is well developed in M. paxillata and forms a prominent tooth. Mallomonas paxillata has smooth bristles with bifurcated tips, contrasting 

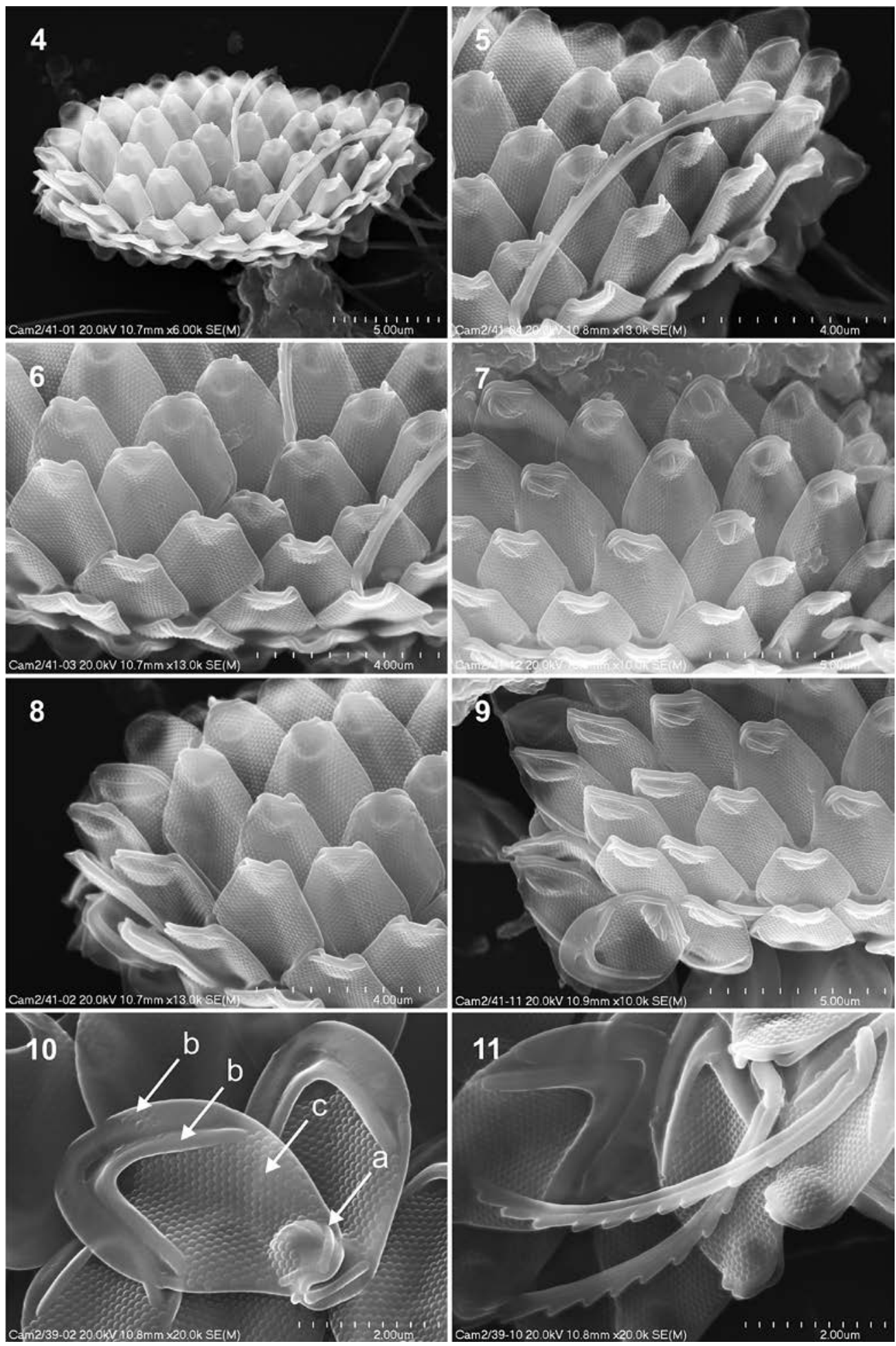
with the serrate bristles of $M$. camerunensis, and larger scales $(4.0-5.7 \mu \mathrm{m} \times 2.5-4.0 \mu \mathrm{m})$.

Mallomonas camerunensis resembles $M$. rasilis Dürrschm. but differs in having a dome ornamented with papillae and ribs, as well as a smooth posterior rim. This contrasts with the smooth dome and the posterior rim ornamented with irregular struts of $M$. rasilis. Moreover, $M$. rasilis has $\mathrm{ca} 7-8$ papillae per scale width (counted in place where V-rib ends, from pictures in Kristiansen 2002; Kristiansen \& Preisig 2007) (18-22 in M. camerunensis).

Mallomonas tropica Dürrschm. \& Croome has similar markings but $M$. camerunensis has a dome ornamented with papillae and ribs, whereas $M$. tropica has a small rounded dome which is not clearly delimited from the shield. Mallomonas camerunensis lacks an anterior submarginal rib; $M$. tropica has an anterior submarginal rib ornamented with struts. The bristles in $M$. tropica are longer than in M. camerunensis (8-16 $\mu \mathrm{m}$ vs. 6.5-11.2 $\mu \mathrm{m})$. Finally, $M$. tropica has $c a 9-10$ papillae per scale width (counted in place where V-rib end, from pictures in Kristiansen 2002; Kristiansen \& Preisig 2007) (18-22 papillae in M. camerunensis).

ACKNOWLEDGEMENTS. I am grateful to Gertrud Cronberg (Lund), Marcin Piątek (Kraków) and an anonymous reviewer for valuable comments and improvements of the manuscript, and to Anna Łatkiewicz (Kraków) for assistance with SEM imaging. This work was supported in part by the W. Szafer Foundation for Polish Botany and in part through statutory funds of the W. Szafer Institute of Botany of the Polish Academy of Sciences, Kraków.

\section{REFERENCES}

Asmund B. \& Kristiansen. J. 1986. The genus Mallomonas (Chrysophyceae). A taxonomic survey based on the ultrastructure of silica scales and bristles. Opera Bot. 85: $1-128$.
COMPÈRE P. 1973. Mallomonas portae-ferreae Péterfi \& Asmund (Chrysophycées) au lac Tchad. Bull. Jard. Bot. Natl. Belg. 43: 235-237.

COMPÈRE P. 1974. Mallomonas bronchartiana, Chrysophycée nouvelle du lac Tchad. Bull. Jard. Bot. Natl. Belg. 44: 61-63.

Compère P. 1975. Algues de la Région du lac Tchad III. Rhodophycées, Euglenophycées, Cryptophycées, Dinophycées, Chrysophycées, Xathophycées. Cah. O.R.S.T.O.M., Ser. Hydrobiol. 9: 167-192.

Cronberg G. 1989. Biogeography studies. Scaled chrysophytes from the tropics. Beih. Nova Hedwigia 95: 191-232.

Cronberg G. 1996. Scaled chrysophytes from the Okavango Delta, Botswana, Africa. Beih. Nova Hedwigia 114: 91-108.

GuSEv E. S. 2012. A new species of the genus Mallomonas (Synurophyceae), Mallomonas spinosa sp. nov., from Vietnam. Phytotaxa 66: 1-5.

GuSEv E. S. 2015. A new species of the genus Mallomonas (Synurales, Chrysophyceae), Mallomonas fimbriata, sp. nov. Phytotaxa 195(4): 291-296.

Gusev E. S., Doan-Nhu H. \& NGuYen-NGoc L. 2015. Mallomonas cattiensis, sp. nov. (Synurales, Chrysophyceae), a new species from Viet Nam. Phytotaxa 221(2): 188-192.

HANSEN P. 1996. Silica-scaled Chrysophyceae and Synurophyceae from Madagascar. Arch. Protistenk. 147: 145-172.

HANSEN P. \& KRISTIANSEN J. 1995. Mallomonas madagascariensis, M. lemuriocellata and M. crocodilorum (Synurophyceae), three new species from madagascar. Nord. $J$. Bot. 15(2): 215-223.

Kristiansen J. 2002. The genus Mallomonas (Synurophyceae). A taxonomic survey based on the ultrastructure of silica scales and bristles. Opera Bot. 139: 5-218.

Kristiansen J. \& Preisig H. R. 2001. Encyclopedia of Chrysophyte Genera. Biblioth. Phycol. 110: 1-260.

Kristiansen J. \& Preisig H. R. 2007. Chrysophyte and haptophyte algae. 2( 2). Synurophyceae. Spektrum Akademischer Verlag, Berlin.

NĚMcová Y. \& KReIdloví J. 2013. Two new species of Mallomonas (Chrysophyceae: Synurales): Mallomonas temonis and Mallomonas divida. Phytotaxa 87(1): 11-18.

NĚmcová Y., Bulant P., Kristiansen J. 2011. Mallomonas solea-ferrea and Mallomonas siveri (Chrysophyceae/Synurophyceae): two new taxa from the West Cape (South Africa). Nova Hedwigia 93(3-4): 375-384.

Figs 4-11. Mallomonas camerunensis J. Piątek, sp. nov. seen by SEM. 4 - Whole cell with scales and bristles. 5 - Group of anterior scales. $6 \& 7$ - Group of body scales. 8 \& 9 - Group of posterior scales. 10 - Body scales with characteristic features: (a) clearly delimited dome ornamented with papillae and ribs, (b) smooth, unornamented posterior rim and V-rib, (c) shield thickly ornamented with papillae (18-22 papillae per scale width, counted in place where V-rib ends). Individual diagnostic features are arrowed. 11 - Slightly curved, serrate bristles. Scale bars: Figs 4, 7, $9=5 \mu \mathrm{m}$; Figs 5, 6, $8=4 \mu \mathrm{m}$; Figs $10,11=2 \mu \mathrm{m}$. 
Piątek J. \& Mossebo D. C. 2008. Mallomonas striata var. serrata and Synura petersenii f. kufferathii, two silicascaled chrysophytes new to Cameroon. Polish Bot. J. 53(2): 139-143.

Piątek J. \& Piątek M. 2014. Morphological variability of new chrysophyte stomatocyst forming a single-cyst assemblage in a low-conductivity tropical lake in the Guineo-Congolian rainforest. Phytotaxa 174(5): 261-271.

Piątek J., Piątek M. \& Mossebo D. C. 2012. The first discovery of an encysted chrysophyte in Africa: Dinobryon sertularia Ehrenb. from Cameroon. Nova Hedwigia 95(3-4): 391-401.

Piątek J., Piątek M., Zeeb B. A. \& El Shahed A. 2009. Chrysophyte stomatocysts in Africa: the first description of an assemblage in the recent sediments of a thermo-mineral spring in Egypt. Phycologia 48(1): 13-23.

ŘEzÁčoví M. 2006. Mallomonas kalinae (Synurophyceae), a new species of alga from northern Bohemia, Czech Republic. Preslia 78: 353-358.

Siver P. A. 1991. The biology of Mallomonas. Morphology, Taxonomy and Ecology. Developm. Hydrobiol. 63: 1-230.

Vyverman W. \& Cronberg G. 1993. Scale bearing chrysophytes from Papua New Guinea. Nordic J. Bot. 13: 111-120.
Wei Y. X., YuAn X. P. \& Kristiansen J. 2014. Silica-scaled chrysophytes from Hainan, Guangdong Provinces and Hong Kong Special Administrative Region, China. Nordic J. Bot. 32: 881-896.

Woodhead N. \& Tweed R. D. 1957. A check list of tropical West African algae. Hydrobilogia 11: 299-395.

Woodhead N. \& Tweed R. D. 1959. A second check-list of tropical West African algae. Hydrobilogia 15(3): 225-286.

WujeK D. E. \& AsMund B. 1979. Mallomonas cyathellata sp. nov. and Mallomonas cyathellata var. kenyana var. nov. (Chrysophyceae) studied by means of scanning and transmission electron microscopy. Phycologia 18(2): 115-119.

Wujek D. E., Adesalut A. \& Nwankwo D. I. 2004. Silicascaled Chrysophyceae and Synurophyceae (Chrysophyta) from Nigeria. II. Lake Lekki. Tropical Freshwater Biology 12-13: 99-103.

WujeK D. E., Kadiri M. O. \& Dziedzic R. M. 2010. Silicascaled Chrysophyceae and Synurophyceae from Nigeria. III. Chrysophytes from rivers of Edo State. Fottea 10(1): 93-98.

WujeK D. E., Kadiri M. O. \& Dziedzic R. M. 2011. Freshwater silica-scaled chrysophytes, heliozoa and thaumatomonad flagellates from Edo State, Nigeria. African Journal of Aquatic Science 36(2): 207-212. 